\title{
Induced neural differentiation of human mesenchymal stem cells affects lipid metabolism pathways
}

Running title: Neural differentiation and lipid metabolism

${ }^{1}$ Pnina Green, ${ }^{2}$ Inna Kan, ${ }^{3}$ Ronit Mesilati- Stahy, ${ }^{3}$ Nurit Argov-Argaman and ${ }^{2}$ Daniel Offen

${ }^{1}$ Pnina Green, Ronit Mesilati- Stahy, Laboratory of Nutrition and Metabolism Research, Felsenstein Medical Research Center, Sackler Faculty of Medicine, Tel-Aviv University, Rabin Medical Center-Beilinson Campus, Petah-Tikva 49100, Israel

${ }^{2}$ Inna Kan, Daniel Offen, Laboratory of Neurosciences, Felsenstein Medical Research Center, Department of Human Molecular Genetics \& Biochemistry, Sackler Faculty of Medicine, Tel-Aviv University, Israel

${ }^{3}$ Nurit Argov-Argaman, The Department of Animal Science, The Robert H. Smith Faculty of Agriculture, Food and Environment, The Hebrew University of Jerusalem Israel, PO Box 12, Rehovot 76100, Israel

Addresses:

PG - pgreen@post.tau.ac.il

IK - innakan2009@gmail.com

NAA - argov.nurit@mail.huji.ac.il

RMS - Ronit_mesilati@walla.com

DO - danioffen@gmail.com

Corresponding author: Daniel Offen, Ph.D., Laboratory of Neurosciences, Felsenstein Medical Research Center, Sackler Faculty of Medicine, Tel-Aviv University, Rabin Medical Center, Petah-Tikva 49100, Israel danioffen@ gmail.com

Tel. 972523342737 Fax. 97239376130

Abbreviated title: Neural differentiation of MSC and PUFA metabolism

\author{
Abbreviations: \\ ACSL, acyl-CoA synthetase long-chain family member; ARA, arachidonic acid; \\ bFGF, basic fibroblast growth factor; $\mathrm{BF}_{3}$, boron trifluoride; $\mathrm{BHA}$, butylated \\ hydroxyanisole; \\ DAPI, 4,6-diamidino- 2-phenylindole; dbcAMP, dibutyryl cyclic AMP; DHA, \\ docosahexaenoic acid; \\ EGF, epidermal growth factor; EPOX, epoxygenases; \\ FABP, fatty acid binding protein; FAME, fatty acid methyl ester; FCS, fetal calf serum; \\ GAPDH, glyceraldehyde 3-phosphate dehydrogenase; \\ IBMX, 3-isobutyl-1-methyl-xanthine; \\ LOX, lipoxygenases; \\ MSC, mesenchymal stem cells; \\ NeuN, anti neuronal nuclei; NGF, nerve growth factor;
}


PL, phospholipid; PUFA, polyunsaturated fatty acids; PtdCho, phosphatidylcholine; PtdEtn, phosphatidylethanolamine; PtdSer, phosphatidylserine; PtdIns, phosphatidylinositol; PLA 2 , phospholipase $\mathrm{A}_{2}$; PCA, principal components analysis; $\mathrm{PGI}_{2}$, prostacyclin; $\mathrm{PG}$, prostaglandin; $\mathrm{PGE}_{2}$, prostaglandin $\mathrm{E}_{2}$;

$\mathrm{RA}$, retinoic acid.

\begin{abstract}
Neuronal membranes contain exceptionally high concentrations of long-chain polyunsaturated fatty acids (PUFA), docosahexaenoic acid (DHA) and arachidonic acid (ARA), which are essential for neuronal development and function. Adult bone-marrowderived mesenchymal stem cells (MSC) can be induced to possess some neuronal characteristics. Here we examined the effects of neuronal induction on the PUFA metabolism specific pathways. Differentiated cells contained $\sim 30 \%$ less ARA than MSC. The expression of specific ARA metabolizing enzymes was upregulated, notably that of prostaglandin $\mathrm{E}_{2}$ synthase which increased more than 15-fold, concomitantly with a 3fold increase in the concentration of $\mathrm{PGE}_{2}$ in the medium. Moreover, induced differentiation was associated with enhanced incorporation of exogenous DHA, upregulation of acyl-CoA synthases, fatty acid binding proteins, choline kinase (CK) and phosphatidylserine synthases as well as increased total cellular phospholipids (PL). These findings suggest that active ARA metabolites may be important in the differentiation process and that neuronal induction prepares the resulting cells for increased DHA incorporation through the action of specific enzymes.
\end{abstract}

Keywords: Adult stem cells, ARA, DHA, Lipid metabolism, Neural differentiation

\title{
Introduction
}

One of the major features of neuronal tissue is the high proportion of the longchain polyunsaturated fatty acids (PUFA) docosahexaenoic acid (DHA, 22:6 n-3) and arachidonic acid (ARA, 20:4 n-6) in neuronal membranes. These PUFA are important for multiple aspects of neuronal development and function, including neurite outgrowth [13], signal transduction, and membrane fluidity [4]. The incorporation of DHA in the nerve membranes during perinatal development is essential to the development of cerebral and retinal functions [5]. Moreover, DHA promotes the differentiation of neuronal stem cells in vitro and in vivo [6]. Although DHA is found in abundance in neuronal tissue, it cannot be synthesized by neurons and has to be supplied by cerebrovascular endothelium and astrocytes [7].

Long-chain PUFA are primarily incorporated into the $s n-2$ position of the phospholipids (PL). DHA is incorporated mainly into phosphatidylethanolamine (PtdEtn) and phosphatidylserine (PtdSer), whereas ARA is incorporated into phosphatidylinositol (PtdIns), PtdEtn and phosphatidylcholine (PtdCho) [8]. It has been repeatedly shown that DHA promotes PtdSer biosynthesis and accumulation $[9,10]$ and inhibits apoptosis in neuronal cells in a PtdSer-dependent manner [10]. The increase of PtdSer levels upon DHA enrichment is not a universal mechanism, but specific to neuronal cells [11]. 
Adult autologous bone-marrow-derived mesenchymal stem cells (MSC) are able to differentiate beyond tissues of mesodermal origin into neuron-like cells, displaying a variety of neuronal attributesand markers of neuronal transmission [12]. Our group has previously reported a novel protocol for neuronal induction of MSC [13] and stressed the necessity of exogenous PUFA supplementation to this process [14]. Given the unique PUFA composition of neuronal tissue, we asked whether specific related metabolic pathways would be altered following induced differentiation. In the present study we report that, indeed, following neuronal induction specific changes occur, which include decreased ARA concentration, increased secretion of prostaglandin $\mathrm{E}_{2}\left(\mathrm{PGE}_{2}\right)$, increased incorporation of supplemented DHA, increased cellular PL, especially PtdCho and altered expression of related metabolizing enzymes. These results highlight the involvement of specific lipid pathways in neuronal development.

\section{Materials and methods}

Isolation and culture of human mesenchymal stem cells

Human MSC were purchased from Lonza, Inc. (Swiss) and cultured and expanded as previously described [15]. Briefly, cells were diluted 1:1 with Hank's balanced salt solution (HBSS; Biological Industries, Beit-Haemek, Israel). Mononuclear cells were recovered from the fractionated suspension following centrifugation in UnisepMaxi tubes (Novamed, Jerusalem, Israel) at $1000 \mathrm{~g}$ for $20 \mathrm{~min}$ at room temperature. The cells were resuspended in growth medium containing Dulbecco's modified Eagle's medium (DMEM; Biological Industries) supplemented with 15\% fetal calf serum (FCS; Biological Industries), $2 \mathrm{mM}$ L-glutamine (Biological Industries), $100 \mu \mathrm{g} / \mathrm{mL}$ streptomycin, $100 \mathrm{U} / \mathrm{mL}$ penicillin, $12.5 \mathrm{U} / \mathrm{mL}$ nystatin (SPN; Biological Industries) and plated in polystyrene plastic $75-\mathrm{cm} 2$ tissue-culture flasks (Corning, Corning, NY). Nonadherent cells were removed after $24 \mathrm{~h}$ with medium replacement. Adherent cells was cultured to $70 \%-90 \%$ confluence and reseeded at a density of 5,000-10,000 cells $/ \mathrm{cm}^{2}$. The cells were maintained at $37^{\circ} \mathrm{C}$ in a humidified $5 \% \mathrm{CO}_{2}$ incubator.

Neuronal induction

Growth medium was replaced with Differentiation Medium I consisting of DMEM supplemented with $10 \%$ FCS, $2 \mathrm{mM}$ glutamine, SPN, $10 \mathrm{ng} / \mathrm{mL}$ basic fibroblast growth factor (bFGF; R\&D Systems, Minneapolis, MN), $10 \mathrm{ng} / \mathrm{mL}$ epidermal growth factor (EGF; R\&D systems), and N2 supplement ( $5 \mu \mathrm{g} / \mathrm{mL}$ insulin; $20 \mathrm{nM}$ progesterone; $100 \mu \mathrm{M}$ putrescine; $30 \mathrm{nM}$ selenium; $100 \mu \mathrm{g} / \mathrm{mL}$ transferrin). Seventy-two hours later, the medium was replaced with Differentiation Medium II containing DMEM supplemented with SPN, $2 \mathrm{mM}$ L-glutamine, N2 supplement, $200 \mu \mathrm{M}$ butylated hydroxyanisole (BHA; Sigma, St. Louis, MO), $1 \mathrm{mM}$ dibutyryl cyclic AMP (dbcAMP; Sigma), 3-isobutyl-1-methyl-xanthine (IBMX; Sigma) and $1 \mu \mathrm{M}$ all-trans-retinoic acid (RA; Sigma) for 48 hours.

Serum deprivation

Growth medium was replaced with low serum medium containing DMEM supplemented with $10 \%$ FCS, $2 \mathrm{mM}$ glutamine and SPN. Forty-eight hours later the medium was changed into serum free medium containing DMEM, 2mM glutamine and SPN.

Immunocytochemistry 
Cells were fixed with $4 \%$ paraformaldehyde and permeabilized/blocked in $3 \%$ normal goat serum, $1 \%$ bovine serum albumin (Sigma), and $0.1 \%$ Triton-X in PBS for 1 hour at room temperature. The cells were incubated with either mouse anti- $\beta 3$-tubulin (TUJ1; 1:1000; Sigma) or mouse anti neuronal nuclei (NeuN; 1:10; Chemicon) for 24 hours at $4^{\circ} \mathrm{C}$. NeuN staining was followed by goat anti-mouse Alexa-568 (1:1000, Molecular Probes). TUJ1 primary antibody was followed by goat anti mouse biotinilated (ready to use, Zymed) for 1 hour at room temperature followed by Streptavidin Alexa488 (1:200, Molecular Probes). DNA-specific fluorescent dye 4,6-diamidino- 2phenylindole (DAPI; Sigma) counterstain was used to detect cell nuclei. Cells were photographed with a fluorescence Olympus IX70-S8F2 microscope with a fluorescent light source (excitation wavelength, 330-385 nm; barrier filter, $420 \mathrm{~nm}$ ) and a U-MNU filter cube (Olympus, Center Valley, PA).

Fatty acid supplementation and analysis

For the DHA incorporation experiments 30, 40, 50 or $60 \mu \mathrm{M}$ DHA (Sigma) coupled with $1 \%$ horse serum (Biological Industries) and diluted in DMEM was supplemented to the growth medium or to the Differentiation Medium I.

For fatty acid analysis, following aspiration of the medium, cultures were washed with PBS, and lipids were extracted with hexane (BioLab, Jerusalem, Israel)/isopropanol (Sigma) $(3: 2, \mathrm{v} / \mathrm{v})$ containing $5 \mathrm{mg} / 100 \mathrm{~mL}$ butylated hydroxytoluene (Sigma) as an antioxidant. Fatty acids were converted to fatty acid methyl esters (FAME) by heating with $14 \%$ boron trifluoride $\left(\mathrm{BF}_{3}\right)$ in methanol (Sigma) and separated on capillary columns in an HP 5890 Series II GLC equipped with a flame ionization detector. Peak areas were integrated and plotted with the aid of the Varian Star Integrator computer package. Comparing retention times with authentic standards identified individual FAME. The amount of individual fatty acids is reported as percent peak area (area \%) of total identified FA.

Prostaglandin assay

PGE2 in the media of MSC and differentiated cells was determined by a $\mathrm{PGE}_{2}$ immunoassay (R\&D Systems) according to the manufacturer's instructions.

Phospholipid analysis

Following aspiration of medium, cells were washed with PBS and stored at $-20^{\circ} \mathrm{C}$ until lipid extraction. Total lipids were extracted from cells using a protocol adapted from the cold-extraction procedure developed by Folch et al. [16] with minor modifications, as previously described [17]. Briefly, total lipids were extracted from cells with methanol: chloroform: water solution $(1: 2: 0.6, \mathrm{v} / \mathrm{v})$. After overnight incubation at $4{ }^{0} \mathrm{C}$, the lower, hydrophobic, phase was collected and filtered through a $0.45 \mu \mathrm{m}$ Teflon syringe filter (Axiva Sachem Biotech, India) into a new vial. After solvents were evaporate under $\mathrm{N}_{2}$, total fat was dissolved in $100 \mu \mathrm{L}$ of chloroform: methanol (3\%, v/v) and stored at $-20{ }^{\circ} \mathrm{C}$ until further analysis.

Analysis of Polar and Neutral Lipids. Polar and neutral lipids were identified and quantified by HPLC (HP 1200, Agilent) combined with an evaporative light-scattering detector (ELSD, 1200 series, Agilent) according to a previously described protocol for normal-phase lipid separation [17]. Briefly, the separation protocol consisted of a gradient of dichloromethane, $99 \%$ methanol and 1\% ammonium, and double-distilled 
water using normal-phase chromatography on a silica column (Zorbax RX-SIL, $4.6 \times 250$ $\mathrm{mm}$, Agilent). The column was heated to $40^{\circ} \mathrm{C}$, flow was $1 \mathrm{ml} / \mathrm{min}$, and injection volume was $20 \mu \mathrm{l}$. Detector was heated to $65^{\circ} \mathrm{C}$ and nitrogen pressure was set on 3.8 bars. The separation process was managed by ChemStation software for data acquisition from the ELSD. Lipids were identified by external standards: PE, PS, PI, PC, and SM (Sigma Aldrich, Rehovot, Israel). Quantification was performed against external standard curves. Calibration curves were calculated by applying the power model equations to the concentration values, as following: $\mathrm{PS}, \mathrm{y}=0.0137 \mathrm{X} 0.6339\left(\mathrm{R}^{2}=0.999\right) ; \mathrm{PE}, \mathrm{y}=$ $0.0037 X 0.7398\left(\mathrm{R}^{2}=0.987\right) ; \mathrm{PI}, \mathrm{y}=0.0135 \mathrm{X} 0.5928\left(\mathrm{R}^{2}=0.999\right) ; \mathrm{PC}, \mathrm{y}=0.0056 \mathrm{X} 0.6661$ $\left(\mathrm{R}^{2}=0.99\right) ; \mathrm{SM}, \mathrm{y}=0.0101 \mathrm{X} 0.6976\left(\mathrm{R}^{2}=0.996\right)$.

\section{RNA extraction}

Total RNA was isolated by a commercial Tryzol reagent (Invitrogen, Carlsbad, CA). The amount and quality of RNA was determined with the ND-1000 spectrophotometer (NanoDrop, Wilmington, DE) based on the ratios of 280/260 and 260/230. RNA was DNase (Qiagen, Germantown, MD) treated and cleaned using RNeasy Mini Kit (Qiagen). The overall quality of an RNA preparation was assessed by electrophoresis on a denaturing agarose gel.

\section{Microarray analysis}

MSC derived from three human donors were included in the microarray study. Total RNA from untreated MSC and from differentiated cells was isolated as previously described. RNA labeling, chip hybridization, scanning and data acquisition were performed according to the manual provided by the Affymetrix manufacturer (http://www.affymetrix.com/support/downloads/manuals/wt_sensetarget

label_manual.pdf). Double-stranded cDNA was synthesized with random hexamers tagged with a T7 promoter sequence from $300 \mathrm{ng}$ total RNA. cRNA was generated from the double-stranded cDNA template through an in-vitro transcription reaction and purified using the Affymetrix sample cleanup module. cDNA was regenerated through a random-primed reverse transcription using a dNTP mix containing dUTP. The RNA was hydrolyzed with RNaseH and the cDNA was purified. The cDNA was then fragmented by incubation with a mixture of UDG and APE1 restriction endonucleases and endlabeled via a terminal transferase reaction incorporating a biotinylated dideoxynucleotide. The efficiency of the labeling procedure was assessed by gel shift assay. $2.5 \mu \mathrm{g}$ of the fragmented, biotinylated cDNA was added to a hybridization cocktail, loaded on a Human Gene 1.0 ST GeneChip and hybridized for 16 hours at $45^{\circ} \mathrm{C}$ and $60 \mathrm{rpm}$. Following hybridization, the array was washed and stained on a GeneChip Fluidics Station 450 according to the Affymetrix protocol. The stained array was scanned using an Affymetrix GeneChip Scanner 3000.

\section{Data analysis}

Expression values from the Affymetrix Human Gene 1.0 ST chips were analyzed using Partek Genomics Suite (Partek Inc., St. Louis, MO). Raw intensity values were imported by setting up robust multiarray analysis background correction; quartile normalization, log transformation and median polish summarization. Principal components analysis (PCA) was performed for visualizing high-dimensional data. To identify differential expression between the groups, mixed-model ANOVA with linear 
contrast between two specific groups in the context of ANOVA, as implemented in the Partek software, was applied. $P<0.01$ cut off was applied and data was presented using geometric fold change.

Quantitative reverse transcription polymerase chain reaction (real-time PCR)

Total RNA was isolated as previously described. First-strand cDNA synthesis was carried out with Super Script II RNase H-reverse transcriptase (Invitrogen, New Haven, CT) using a random primer. Real-time PCR was performed in an ABI Prism 7700 sequence detection system (Applied Biosystems, Foster City, CA) using Syber Green PCR Master Mix (Applied Biosystems) and the specific primers (Table 1). The glyceraldehyde 3-phosphate dehydrogenase (GAPDH) gene served as an internal control. The PCR was performed in a total volume of $20 \mu \mathrm{L}$ containing $1 \mu \mathrm{L}$ of the previously described cDNA, the 3' and 5' primers at a final concentration of $500 \mathrm{nM}$ each, $7 \mu \mathrm{L}$ of deionized $\mathrm{H}_{2} \mathrm{O}$ (water DEPC) and $10 \mu \mathrm{L}$ of Syber Green Mix. The amplification protocol included 40 cycles of $95^{\circ} \mathrm{C}$ for $15 \mathrm{sec}$ followed by $60^{\circ} \mathrm{C}$ for $30 \mathrm{sec}$. Quantitative calculations of the gene of interest versus GAPDH was performed according to the $\triangle \Delta \mathrm{CT}$ method, as instructed in the user bulletin of the ABI Prism 7700 sequence detection system (updated 10/2001).

$\underline{\text { Statistics }}$

Data were analyzed using the SPSS software. Statistical analysis of two samples was performed by an Independent Samples two-tailed t-test. The statistical analysis of more than two samples was performed by ANOVA test (Scheffe post hoc comparison). The results were considered significant when $P<0.05$. 


\section{Results}

Induced MSC show neuronal phenotype

Bright-light microscopy revealed that neuronal induction was associated with a morphological change of the cells, from the characteristic fibroblast shaped cells to a neuronal-like appearance (Fig. 1A, B). Immunocytochemical analysis revealed that the induced cells expressed higher levels of TUJ1, a neuronal progenitor marker, than the untreated MSC (Fig. 1E, F). In addition, the induced cells stained positive for the mature neuronal nuclear specific antigen NeuN (Fig. 1C, D).

Neuronal induction reduces the cellular concentrations of ARA

Following neuronal induction, a consistent decrease of ARA concentration was observed, from $8.37 \pm 0.51$ area $\%$ to $6.1 \pm 0.64$ area $\%(P=0.03,22$ samples of seven independent experiments) (Fig. 2). The only other significant change was an increase in the concentration of $20: 3 \mathrm{n}-6$ (from $1.57 \pm 0.12$ area $\%$ to $2.15 \pm 0.15$ area $\%$ ). No differences were found in the n-3 PUFA or the other fatty acid subgroups (not shown).

The decreased concentration of ARA is not due to non-specific stress

Since neuronal induction involves removal of serum from the culture upon the final step of culture in Differentiation Medium II (Materials and Methods), a procedure which entails cellular stress [18], we checked whether serum removal might cause the decreased ARA. In MSCs without differentiation the concentration of ARA was 10.12 \pm 1.07 area $\%$, whereas upon serum removal the value remained virtually unchanged: 10.65 \pm 0.17 area $\%$. Thus, serum removal did not affect the cellular concentration of ARA. Specific pathways of ARA metabolism are affected by neuronal induction

Gene expression analysis related to ARA metabolism was performed in order to elucidate the observed decrease of ARA concentration. Microarray analysis of mRNA expression of MSC obtained from three human donors, before and after neuronal induction, included significant changes in phospholipases, in the cyclooxygenase pathway and the cytochrome P450 pathway (Fig. 3 and Supplements Table 1-4). Figure 3 is a cartoon depicting the major metabolic pathways of ARA in which the observed changes are noted. In particular, the phospholipases $\mathrm{A}_{2}$ ( $\left.\mathrm{PLA}_{2}\right)$ increased 2-4 fold, cyclooxygenase $2\left(\mathrm{COX}_{2}\right)$ increased almost 42 -fold and prostaglandin $\mathrm{E}_{2}\left(\mathrm{PGE}_{2}\right)$ synthase increased 15-fold. Downregulation of prostacyclin $\left(\mathrm{PGI}_{2}\right)$ synthase more than 9fold was also noticed. No significant changes were recorded in the major enzymes of the lipoxygenase pathway and only a minor downregulation was observed in the cytochrome P450 pathway (Fig. 3).

Neuronal induction is associated with increased $\mathrm{PGE}_{2}$ secretion

Immunoassay of the media for PGE2 from undifferentiated and differentiated cells showed a 3-fold increase upon differentiation induction (Fig. 4), in accord with the major upregulation observed for the enzymes participating in its synthesis.

Neuronal induction affects the incorporation of supplemented DHA

MSC following neuronal induction (Diff.) demonstrated considerable incorporation of DHA as opposed to undifferentiated MSC (Fig. 5). In dose-response experiments, differentiated cells incorporated more DHA at various supplemented concentrations, whereas the corresponding curve in the MSC remained almost flat. Specifically, the DHA concentration in differentiated cells supplemented with $30 \mu \mathrm{M}$ 
DHA was $11.58 \pm 1.92$ area $\%$ vs. $7.87 \pm 0.82$ area $\%$ in undifferentiated cells supplemented with identical concentration of DHA. Following the supplementation of 40 $\mu \mathrm{M}$ DHA, DHA concentration was $15.88 \pm 0.83$ area $\%$ in differentiated cells vs. $8.36 \pm$ 0.12 area $\%$ in undifferentiated cells. While the cellular concentrations of DHA kept climbing in the differentiated cells with increasing concentrations of the supplemented DHA, to $17.54 \pm 1.19$ area $\%$ following supplementation of $50 \mu \mathrm{M}$ DHA and to $21.60 \pm$ 0.21 area $\%$ following supplementation of $60 \mu \mathrm{M}$ DHA, the cellular concentrations of DHA in the undifferentiated cells remained unchanged $(\sim 8.5$ area $\%)$.

In the differentiated cells, an approximately $45 \%$ decrease was observed in the total monounsaturated fatty acids (MUFA) upon increasing the added DHA from $0 \mu \mathrm{M}$ to 60 $\mu \mathrm{M}$ and the total n-6 PUFA decreased by approximately $18 \%$. The saturated fatty acids remained unchanged (not shown).

Microarray analysis of mRNA expression of enzymes and proteins involved in PL and PUFA metabolism is affected by neuronal induction

The main changes in PL synthesizing enzymes before and after the neuronal induction involved upregulation of PtdCho and PtdSer synthesis, namely, that of choline kinase $(\mathrm{CK})$ which increased more than two-fold and of PtdSer synthases I and II, both which increased 1.5-fold (Data not shwen).

Enzymes involved in PUFA metabolism, which were affected by neuronal induction included a more than 10-fold upregulation of fatty acid binding protein 5 (FABP5), almost 6-fold upregulation of acyl-CoA synthetase long-chain family member 1 (ACSL1), almost 3-fold upregulation of ACSL3 and more than 11-fold upregulation of ACSL4 (Table 2 and Supplements Table 5).

$\underline{\text { Real-time PCR }}$

Analysis of PL synthesizing enzymes showed that neuronal induction increased the expression of CTP:phosphocholine cytydyltransferase beta (CCTb), PtdSer synthase I and PtdSer synthase II, enzymes which participate in the synthesis of PtdCho and PtdSer (Fig. 6).

Cellular PL composition is affected by neuronal induction

Total cellular PLs increased in the cells following neuronal induction $\left(74.7 \pm 9.4 \mathrm{mg} / 10^{6}\right.$ cells vs. $43.1 \pm 8.0 \mathrm{mg} / 10^{6}$ cells, $\left.\mathrm{p}=0.01\right)$, mainly due to increase of PtdCho (45.2 \pm 5.7 vs. $22.9 \pm 3.8 \mathrm{mg} / 10^{6}$ cells, $\left.\mathrm{p}=0.005\right)$.

\section{Discussion}

In this study we demonstrated several changes involving lipid metabolism in MSC undergoing neuronal induction, especially in the cellular content of ARA and DHA. The findings related to ARA may point towards possible role of its metabolites in neuronal differentiation, whereas those related to DHA suggest that cells differentiating into neural cells are "primed" to increase their DHA accretion.

One of the effects of the neuronal induction was the decrease in the cellular levels of ARA. This decrease was induced by defined conditions of the induction protocol and did not occur following unspecific stress caused by serum deprivation. 
The observed upregulation in the expression of $\mathrm{PLA}_{2}$ (more than 4-fold) and $\mathrm{PGE}_{2}$ synthase 1 (more than 15-fold), together with a 3-fold increase in $\mathrm{PGE}_{2}$ secretion are probably related to the decreased ARA, as detailed below.

Enzymatic oxidation of ARA includes three major metabolic pathways: COX, lipoxygenases (LOX) and epoxygenases (EPOX) which metabolize ARA to prostaglandins (PG), thromboxanes, leukotrienes, and epoxyeicosatrienoic acid, respectively. These metabolites are collectively referred to as eicosanoids and play important roles in regulating signal transduction and gene transcription processes [19]. Although the function of PG in the CNS has been studied mostly in relation to disease, eicosanoids in general and PG in particular, have important physiological functions. They play important roles in neural function including sleep induction, long term potentiation, spatial learning and synaptic plasticity [20]. Specifically, the stimulation of pheochromocytoma $\mathrm{PC}_{12}$ cells with nerve growth factor (NGF) results in outgrowth of neurites. This stimulation increases arachidonate metabolism and eicosanoid production, while inhibitors of PLA 2 and lipoxygenase metabolism prevent neurite outgrowth [21]. Moreover, retinoic acid, a component of the differentiation medium in the present study and a well-known mediator of differentiation in neural cultures, has been postulated to be involved with the release of ARA by $\mathrm{PLA}_{2}$ and generation of eicosanoids [22]. From these considerations we suggest that the observed ARA decrease might be essential for the differentiation process, by the generation of oxidized active ARA metabolites.

The fundamental difference between MSC and differentiated cells regarding DHA accumulation in the present study is shown in Figure 5. It is well known that neuronal tissue is especially enriched in DHA, and here we demonstrate the profound change that cells undergo once they are induced to differentiate toward neuronal cells, leading to their ability to avidly accumulate supplemented DHA. In order to unravel some of the fatty acid-related mechanisms leading to neuronal differentiation, including the ability of neuronal tissue to accumulate DHA, we compared the expression of several related enzymes and proteins in MSC before and after neuronal induction (Fig. 3, 6, Table 2, Supplements). Specifically, a significant upregulation was recorded in the levels of the fatty acid binding protein (FABP) 5 (EFAB), of the acyl-CoA synthases ACSL1, ACSL 3 and ACSL 4, and a significant increase in the expression of choline kinase, PtdSer synthase I and PtdSer synthase II.

While it remains controversial how fatty acids cross the plasma membrane, considerable evidence implicate diffusion through the PL bilayer [23] as well as the involvement of several proteins - FABP - as facilitators of free fatty acid transport across the lipid bilayer [24]. FABP belong to the family of the intracellular lipid-binding proteins that are expressed in vertebrate tissues. FABP enhance both fatty acid uptake and intracellular esterification, but distinct FABP types differentially affect these processes [25]. Expression of three FABP types was detected in the brain: FABP3, FABP5 and FABP7 $[24,25]$. Studies with PC $_{12}$ cells revealed that FABP5 (formerly known as EFABP) has high affinity to a broad range of fatty acids involved in axonal growth and is needed for normal neurite formation during neuronal differentiation [26]. In a mouse model it was demonstrated that FABP7 and FABP5 play essential roles in postnatal differentiation of neural stem cells [27], while in another study it was shown in vitro and in vivo that FABP5 binds to DHA and is involved in the brain endothelial cell uptake and subsequent supply of 
this essential fatty acid to the brain [28]. In our study, we found a significant upregulation of FABP5 (EFABP) upon neuronal induction of MSC, whereas FABP3 (HFABP) was slightly down-regulated and the expression of FABP7 (BFABP) did not change. (Supplement Table 6). We suggest that the increased expression of FABP5 following differentiation induction could be associated with the impressive accumulation of DHA in the differentiated cells (Fig. 5).

Following internalization, fatty acids are activated primarily by ACSL. Five mammalian ACSL have been identified. ACSL1 and ACSL5 activate most unsaturated FA similarly, whereas ACSL3, ACSL4, and ACSL6 (formerly ACS2) preferentially activate PUFA [29]. We observed the upregulation of three of the ACSL following neuronal differentiation (Table 2). Particularly noteworthy is the 11.4-fold increase in the expression of ACSL4, which has been shown to have a very high affinity for both ARA and DHA [30] Moreover, it is highly expressed in brain and is involved in neural differentiation through its role in ARA metabolism [31]. Therefore, this upregulation is consistent with the observed changes in both fatty acids following neuronal induction, namely decreased ARA and increased incorporation of DHA. Interestingly, the expression of ACSL6 remained unchanged (Supplement Table 5).

Neuronal differentiation is associated with increased neurite outgrowth and membrane synthesis, which involve increased PtdCho synthesis [32]. In the present study, the almost 2-fold increase in the PtdCho levels in the differentiated cells was associated with a more than 2-fold increase in the expression of $\mathrm{CK}$, the first enzyme of PtdCho synthesis [32], as well as a significant increase in the expression of CCTb (Fig. $6)$.

Upon differentiation induction we observed upregulation of the expression of PtdSer synthase I and PtdSer synthase II, which catalyze the synthesis of PtdSer from PtdCho and PtdEtn, respectively (Fig. 6). The amount of PtdSer remained unchanged following differentiation, but it is expected to increase with DHA supplementation (Reviewed in [10]).

In summary, we show that neuronal induction of MSCs results in changes of lipid elements characteristic of neuronal cells. Further, we demonstrate some of the mechanisms involved in the PUFA metabolic pathways following neuronal induction. We suggest that active oxidized metabolites of ARA, especially $\mathrm{PGE}_{2}$, may be important for the differentiation process. Specific enzymatic pathways are induced to facilitate the incorporation of cellular DHA and the synthesis of PtdSer: the latter's importance together with DHA for proper neuronal function and survival has amply been documented. Extended lipidomic analysis and detailed examination of involved enzymes should be the supplementary steps in future studies. We hope that unraveling the mechanisms involved in the interaction between induced neuronal differentiation of mesenchymal stem cells and PUFA metabolism will help clarify the roles of the exceptionally high proportion of ARA and DHA in neuronal tissue.

\section{Acknowledgments:}

This work was supported in part by the Public Committee for the Designation of Estate Funds, the Ministry of Justice, Israel (P.G., D.O.), by the Devora Eleonora 
Kirshman Fund for Research of Parkinson's Disease, Tel Aviv University and by the Norma and Alan Aufzein chair of Research of Parkinson's Disease.

This work was performed in partial fulfillment of the requirements for a Ph.D. degree of I.K., Sackler Faculty of Medicine, Tel Aviv University, Israel. The authors thank Ms. Aviva Kluska at FMRC, Dr. Shlomo Bulvik at Laniado Medical Center, Natanya, Israel, Dr. Metsada Pasmanik-Chor and Dr. Varda Oron-Karni, Tel-Aviv University Bioinformatics Unit, Tel Aviv. 


\section{References}

1. Bazinet RP and S Layé (2014) Polyunsaturated fatty acids and their metabolites in brain function and disease. Nat Rev Neurosci 15:771-785.

2. Robson LG, S Dyall, D Sidloff and AT Michael-Titus (2010) Omega-3 polyunsaturated fatty acids increase the neurite outgrowth of rat sensory neurones throughout development and in aged animals. Neurobiol Aging 31:678-687.

3. Hea C, X Qua, L Cuib, J Wanga, and JX Kanga (2009) Improved spatial learning performance of fat-1 mice is associated with enhanced neurogenesis and neuritogenesis by docosahexaenoic acid. Proc Natl Acad Sci (USA) 106:11370-11375.

4. Hishikawa D, WJ Valentine, Y lizuka-Hishikawa, H Shindou and T Shimizu (2017) Metabolism and functions of docosahexaenoic acid-containing membrane glycerophospholipids. FEBS Letters 591:2730-2744.

5. Lozada LE, A Desai, K Kevala, J-W Lee and H-Y Kim (2017) Perinatal brain docosahexaenoic acid concentration has a lasting impact on cognition in mice. $\mathbf{J}$ Nutr 147:1624-1630.

6. Mita T, T Mayanagi, H Ichijo, K Fukumoto, K Otsuka, A Sakai and K Sobue (2016)

Docosahexaenoic acid promotes axon outgrowth by translational regulation of Tau and Collapsin Response Mediator Protein 2 expression. J Biol Chem 291:4955-4965.

7. Moore SA (2001) Polyunsaturated fatty acid synthesis and release by brain-derived cells in vitro. J Mol Neurosci 16:195-200.

8. Naudí A, R Cabré, M Jové, V Ayala, H Gonzalo, M Portero-Otín, I Ferrer and R Pamplona (2015) Lipidomics of human brain aging and Alzheimer's disease pathology. Intern Rev Neurobiol 122:133-189.

9. Green P, B Kamensky and E Yavin (1997) Replenishment of docosahexaenoic acid in n-3 fatty acid-deficient fetal rats by intra-amniotic ethyl-docosahexaenoate administration. J Neurosci Res 48:264-272.

10. Kim H-Y, BX Huan, and AA Spector (2014) Phosphatidylserine in the brain: metabolism and function. Prog Lipid Res 56:1-8, 2014

11. Guo M, L Stockert, M Akbar and H-Y Kim (2007) Neuronal specific increase of phosphatidylserine by docosahexaenoic acid. J Mol Neurosci 33:67-73.

12. Chen Y, FYH Teng and BL Tang (2006) Coaxing bone marrow stromal mesenchymal stem cells towards neuronal differentiation: progress and uncertainties. Cell Mol Life Sci 63:1649-1657.

13. Kan I., T Ben-Zur, Y Barhum, YS Levy, A Burstein, T Charlow, S Bulvik, E Melamed and D Offen (2007) Dopaminergic differentiation of human mesenchymal stem cells--utilization of bioassay for tyrosine hydroxylase expression, Neurosci Lett 419:2833. 
14. Kan I., E Melamed, D Offen and P Green (2007) Docosahexaenoic acid and arachidonic acid are fundamental supplements for the induction of neuronal differentiation. J Lipid Res 48:513-517.

15. Barzilay R, I Kan, T Ben-Zur, S Bulvik, E Melamed and D Offen (2008), Induction of human mesenchymal stem cells into dopamine-producing cells with different differentiation protocols. Stem Cells Dev 17:547-554.

16. Folch J, M Lees and G H Sloane Stanley (1957). A simple method for the isolation and purification of total lipids from animal tissues. J Biol Chem 226: 497-509.

17. Mesilati-Stahy, R, U Moallem, Y Magen and N Argov-Argaman (2015). Altered concentrate to forage ratio in cows ration enhanced bioproduction of specific size subpopulation of milk fat globules. Food Chem 179:199-205.

18. Zhu W, J Chen, X Cong, S Hu and X Chen (2006) Hypoxia and serum deprivationinduced apoptosis in mesenchymal stem cells. Stem Cells 24:416-425.

19. Phillis JW, LA Horrocks and AA Farooqui (2006) Cyclooxygenases, lipoxygenases, and epoxygenases in CNS: their role and involvement in neurological disorders. Brain Res Rev 52: 201-243.

20. Tassoni D, G Kaur, RS Weisinger and AJ Sinclair (2008) The role of eicosanoids in the brain. Asia Pac J Clin Nutr 17(S1):220-228.

21. DeGeorge JJ, R Walenga and S Carbonetto (1988) Nerve growth factor rapidly stimulates arachidonate metabolism in PC12 cells: potential involvement in nerve fiber growth. J Neurosci Res 21:323-332.

22. Farooqui AA, P Antony, W-Y Ong, LA Horrocks and L Freysz (2004) Retinoic acidmediated phospholipase $A_{2}$ signaling in the nucleus. Brain Res Rev 45:179- 195.

23. Hamilton JA and K Brunaldi (2007) A model for fatty acid transport into the brain. J Mol Neurosci 33:12-17.

24. Liu R-Z, R Mita, M Beaulieu, Z Gao and R Godbout (2010) Fatty acid binding proteins in brain development and disease. Int J Dev Biol 54:1229-1239.

25. Matsumata M, H Inada and N Osumi (2016) Fatty acid binding proteins and the nervous system: Their impact on mental conditions. Neurosci Res 102:47-55

26. Liu J-W, FG Almaguel, L Bu, DD De Leon and M De Leon (2008) Expression of EFABP in PC12 cells increases neurite extension during differentiation: involvement of n3 and n-6 fatty acids, J. Neurochem. 106:2015-2029.

27. Matsumata M, Sakayori N, Maekawa M, Owada Y, Yoshikawa T and N Osumi (2012) The effects of Fabp7 and Fabp5 on postnatal hippocampal neurogenesis in the mouse. Stem Cells 30:1532-1543. 
28. Pan Y, MJ Scanlon, Y Owada, Y Yamamoto, CJH Porter and JA Nicolazzo (2015) Fatty acid-binding protein 5 facilitates the blood-brain barrier transport of docosahexaenoic acid. Mol. Pharmaceutics 12:4375-4385.

29. Marszalek JR, C Kitidis, CC DiRusso and HF Lodish (2005) Long-chain acyl-CoA synthetase 6 preferentially promotes DHA metabolism. J Biol Chem 280: 10817-10826. 30. Van Horn CG, JM Caviglia, LO Li, S Wang, DA Granger and RA Coleman (2005) Characterization of recombinant long-chain rat acyl-CoA synthetase isoforms 3 and 6: identification of a novel variant of isoform 6. Biochemistry 44:1635-1642.

31. Cho Y-Y (2012) A novel role of brain-type ACS4 isotype in neuronal differentiation. Biochem Biophys Res Commun 419:505-510.

32. Paoletti L, C Elena, P Domizi and C Banchio (2011) Role of phosphatidylcholine during neuronal differentiation. IUBMB Life 63: 714-720. 


\section{Figure Legends}

Figure 1: Neural characteristics of MSC following the induction. (A) Fibroblast-like morphology of MSC. (B) Neural morphology of MSC following the induction (C-F). Immunocytochemistry for neuronal markers TUJ1 and NeuN in induced cells (Diff.) and untreated MSC (MSC).

Figure 2: Fatty acid concentration of MSC upon neural induction. The fatty acid composition of the MSC and differentiated cells (Diff.) was determined by GLC of fatty acid methyl esters, as described in Materials and Methods $(n=7$ independent experiments). Values are expressed as area percentage of the total identified fatty acids, means + SE. $* p<0.05$

Figure 3. Pathways of arachidonic acid metabolism affected by neural induction. MSC were obtained from three human donors and induced to differentiate into neural cells. The change in mRNA levels of ARA metabolizing enzymes that resulted from the induction was evaluated by gene microarray as specified in Materials and Methods. The specified data represent enzymes that recorded significant change $(\mathrm{p}<0.01)$ following the neural induction and their fold change (positive values stand for upregulation and negative values represent downregulation).

PG, prostaglandin; TX, thromboxane. PLA, Phospholipase; COX, Cyclooxygenase; EET, epoxy-eicosatrienoic acids.

Figure 4. Prostaglandin $\mathrm{E}_{2}$ secretion upon neural induction. PGE2 in the media of MSC and differentiated cells (Diff) was determined by a $\mathrm{PGE}_{2}$ immunoassay. Values are mean $+\mathrm{SE}, \mathrm{n}=5, \mathrm{p}<0.03$.

Figure 5. Dose response analysis of DHA supplementation. The concentration of DHA in MSC and differentiated cells (Diff.) cultured in the presence of various concentrations of DHA was determined by GLC, as described in Materials and Methods (two independent experiments, $n=4$ in each experiment). Values are expressed as DHA area percentage of the total identified fatty acids, means \pm SE.

Figure 6. Differential expression of PtdCho and PtdSer metabolizing genes. The expression of the genes was determined by real-time PCR, as specified in Materials and Methods (Representative result from 3 independent experiments). Values are expressed as arbitrary units (AU) relative to the expression of GAPDH $+\mathrm{SD}$.

$* \mathrm{p}<0.05$.

CCTbeta, CTP:phosphocholine cytydyltransferase beta, PSI \& II Synth., PtdSer synthase I\&II, 
bioRxiv preprint doi: https://doi.org/10.1101/2021.01.17.427010; this version posted January 18, 2021. The copyright holder for this preprint (which was not certified by peer review) is the author/funder. All rights reserved. No reuse allowed without permission.

Figure 1
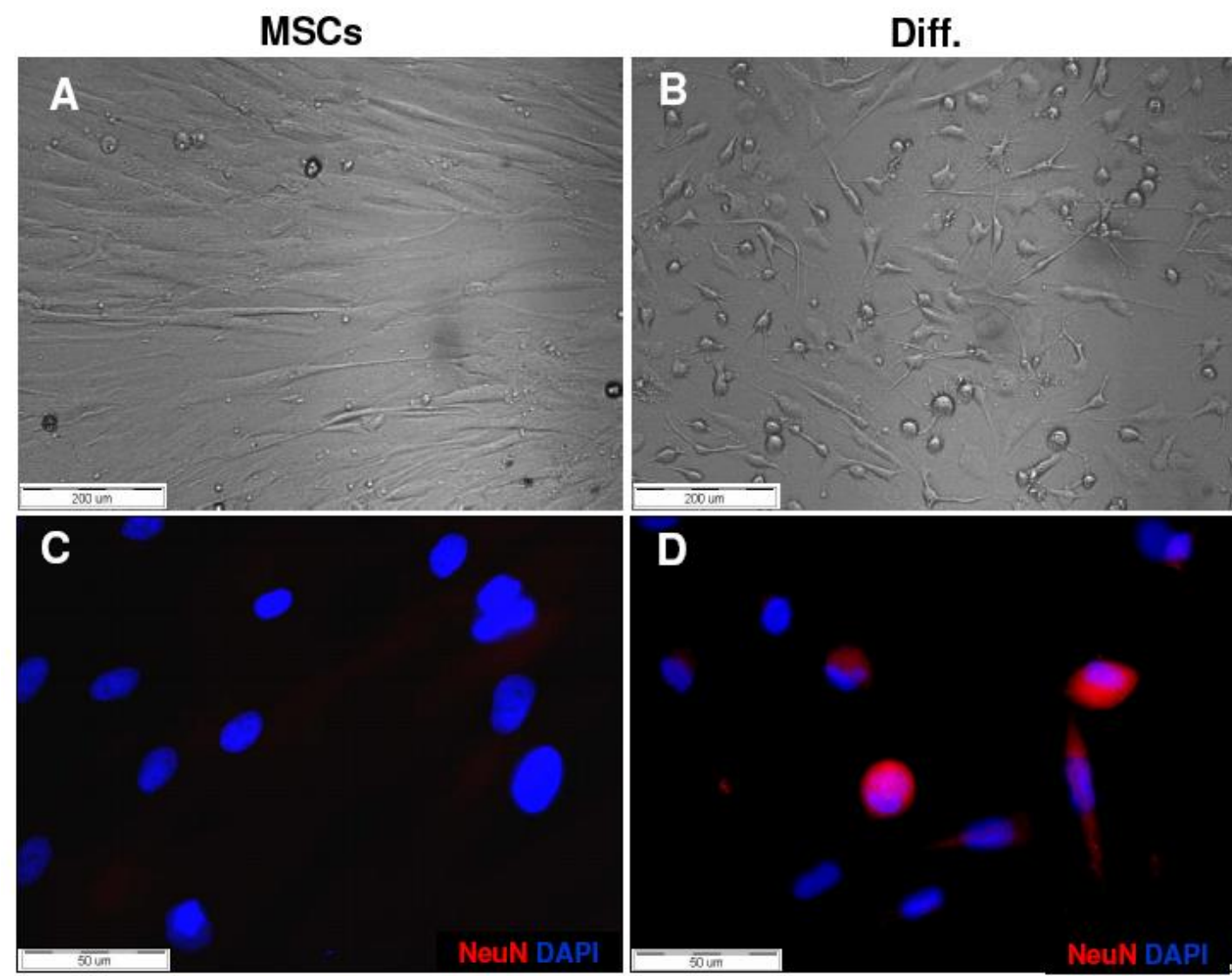

D
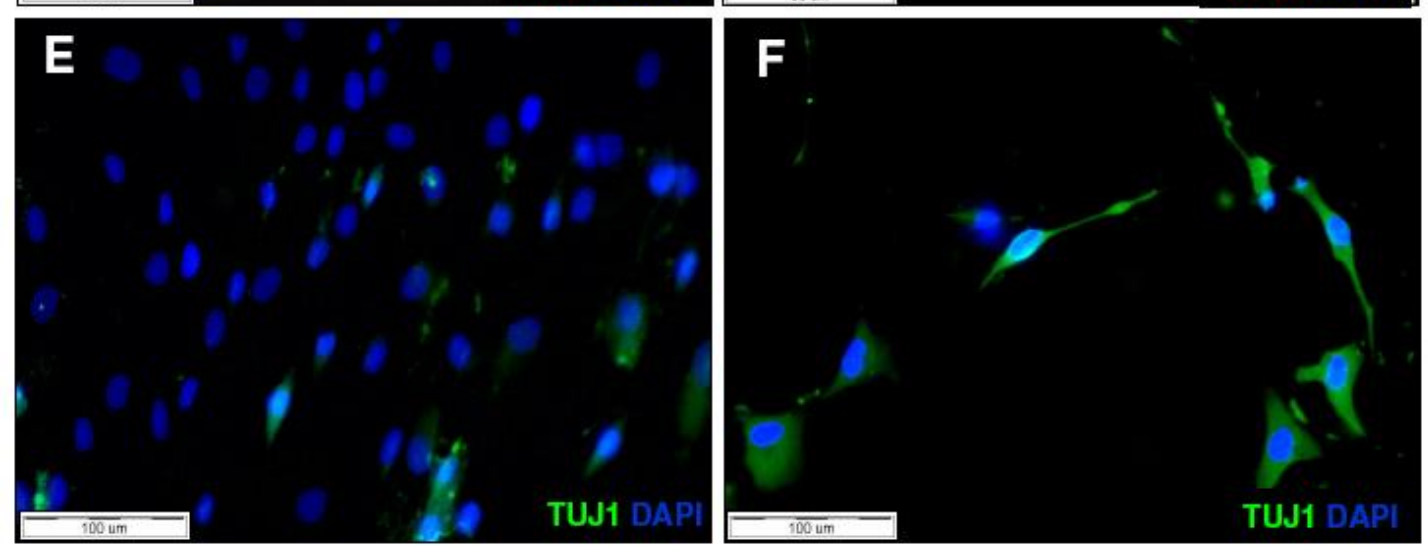
Figure 2

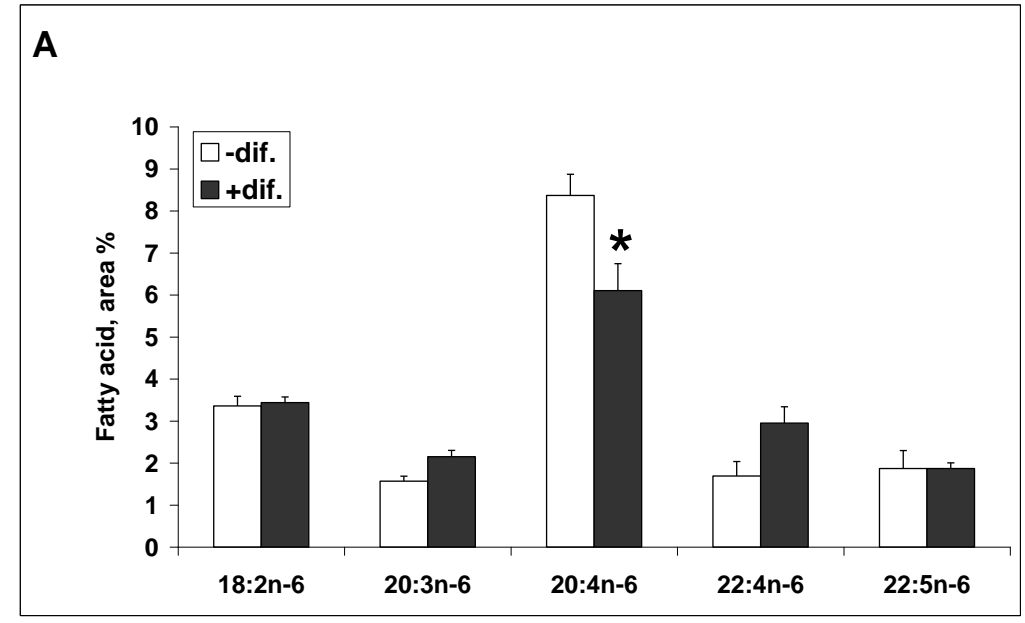

B

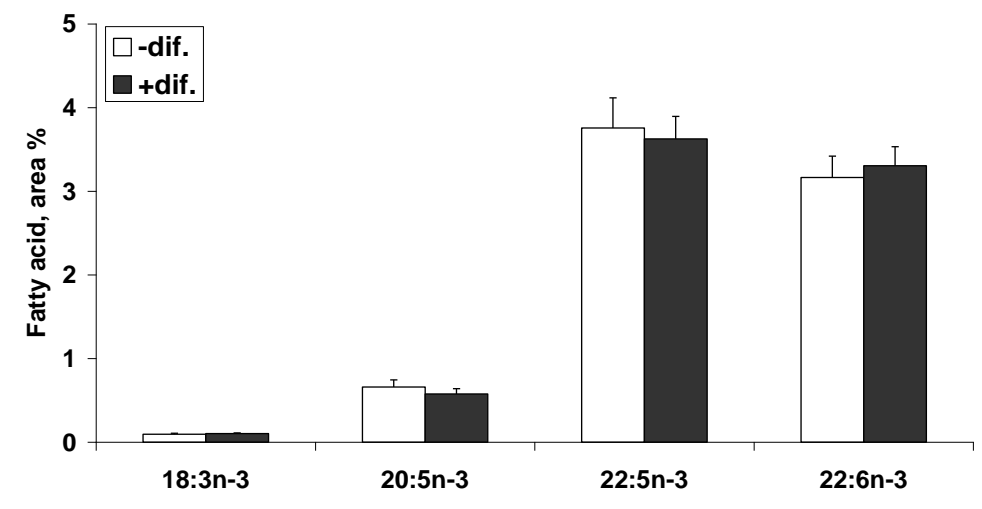

C

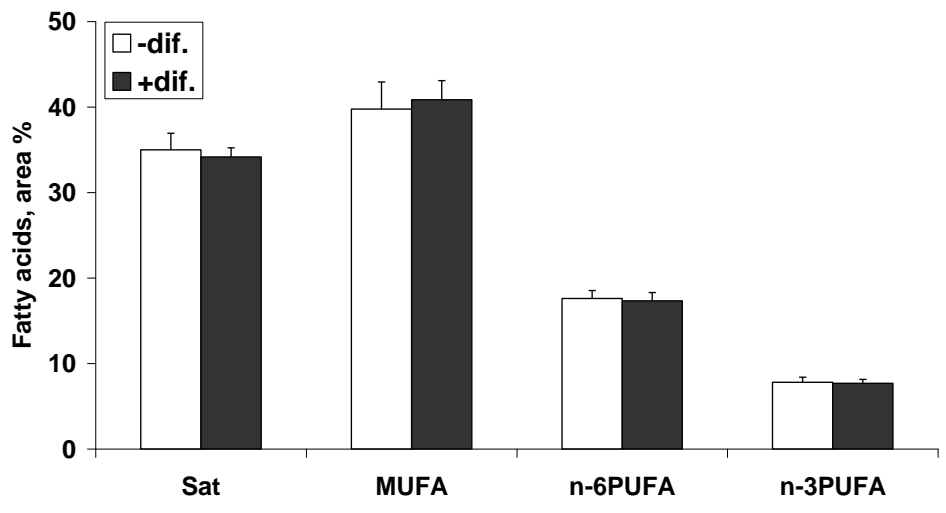


Figure 3

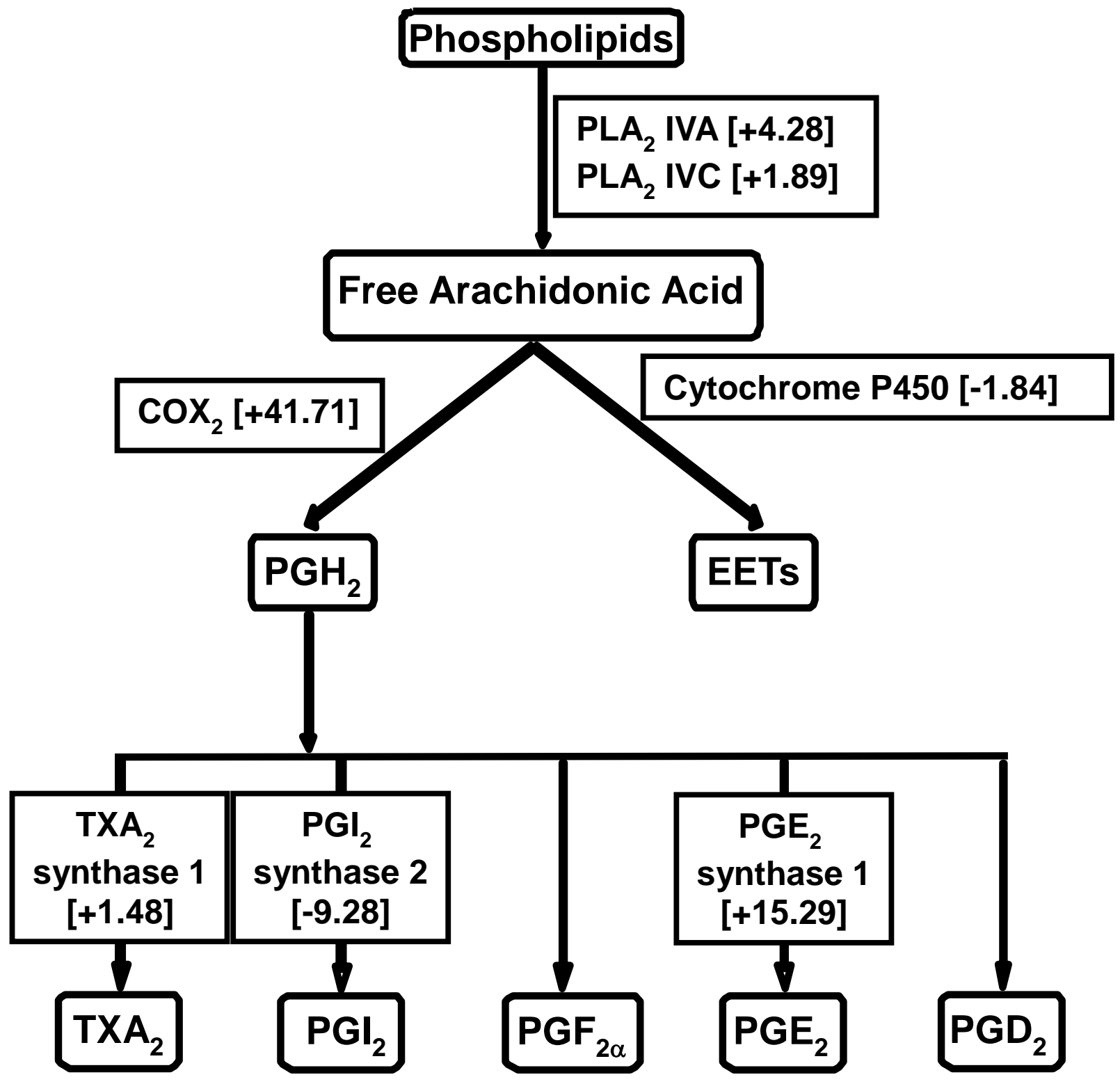




\section{Figure 4}

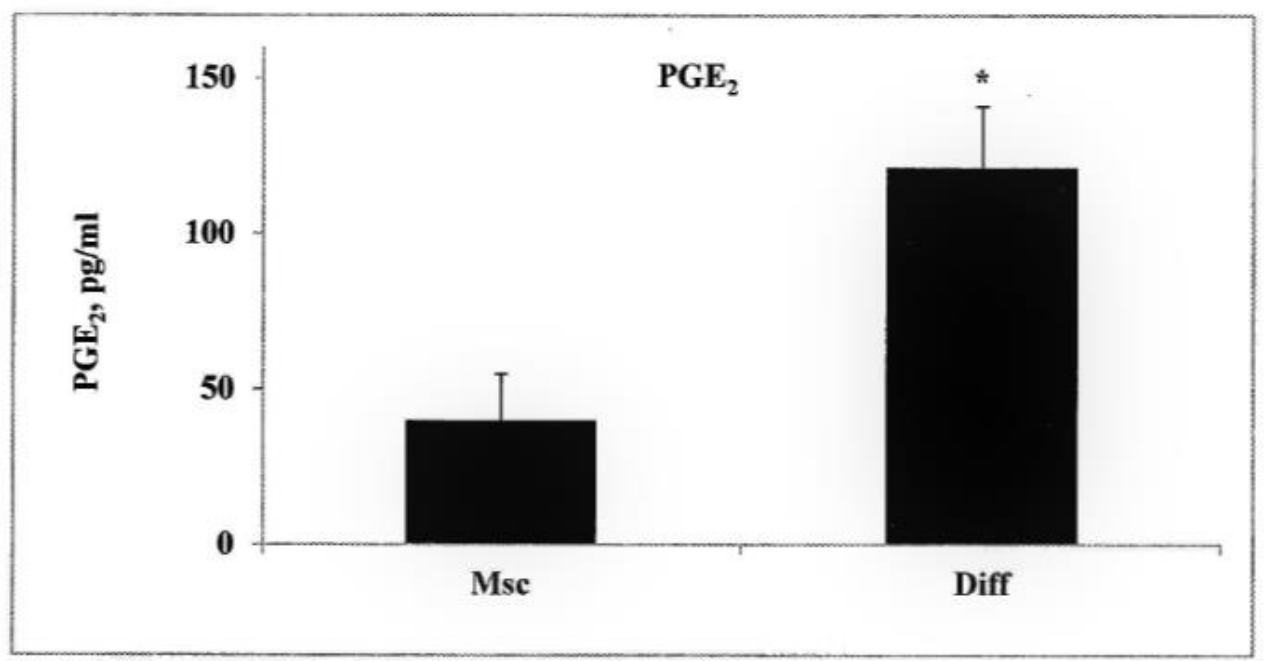

\section{Figure 5}

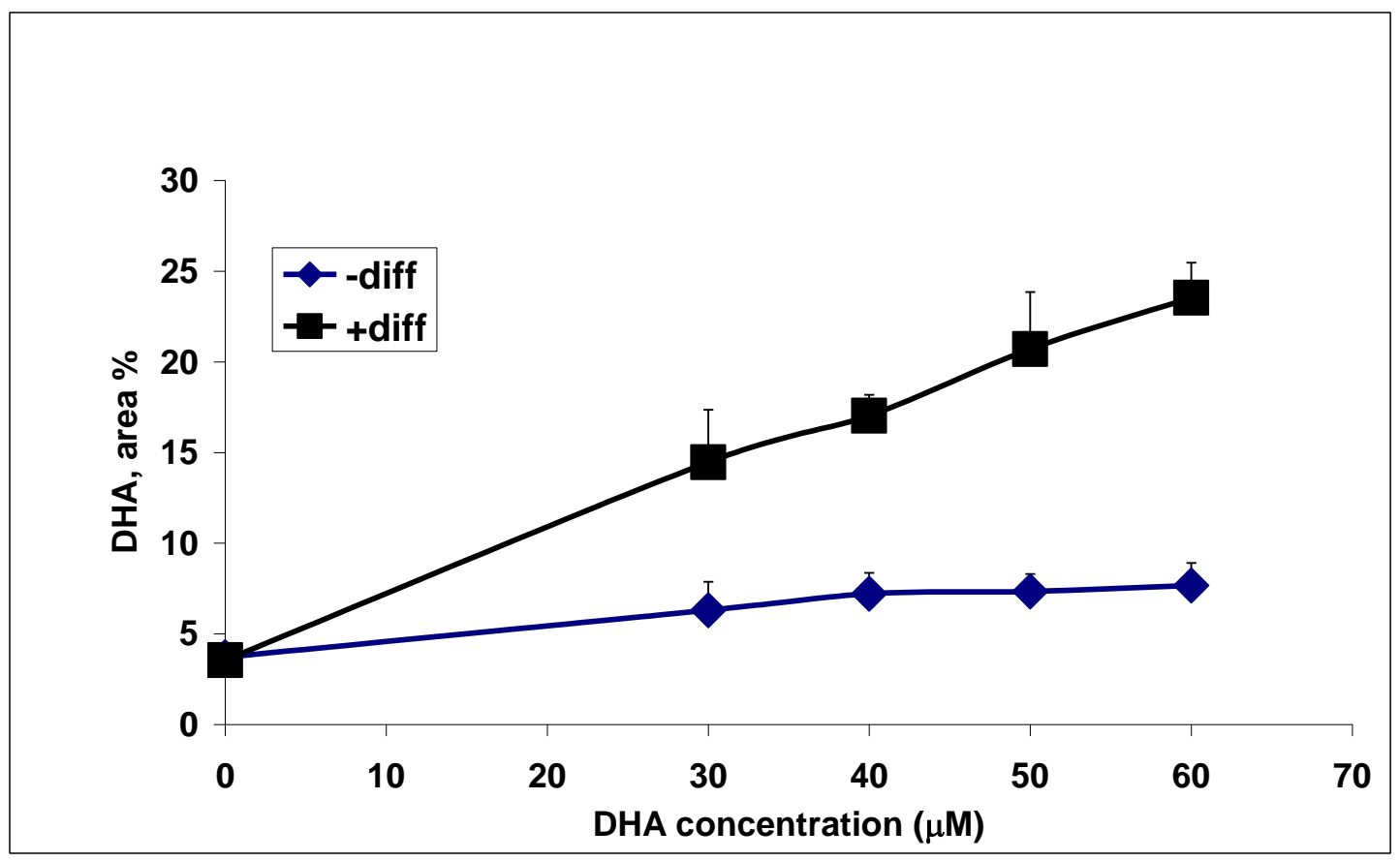




\section{Tables}

\section{Table 1:}

Oligonucleotide sequences of primers used for real-time PCR (Hylabs, Rehovot, Israel)

\begin{tabular}{|c|c|c|}
\hline Name of oligo & Sequence & $\begin{array}{l}\text { Accession } \\
\text { number }\end{array}$ \\
\hline GAPDH sense & CGACAGTCAGCCGCATCTT & \multirow{2}{*}{ NM_002046 } \\
\hline GAPDH antisense & CCARATACGACCARAATCCGTTG & \\
\hline Phosphatidylserine (PtdSer) synthase I & TCCCCARATGGTCCGTTCA & \multirow{2}{*}{ NM_014754 } \\
\hline PtdSer synthase I antisense & $\begin{array}{l}\text { GCTCGARAATTCAGGARAGAGTAG } \\
\text { GA }\end{array}$ & \\
\hline PtdSer synthase II sense & CTTCATCCTCACCTGTACGCTTG & \multirow[b]{2}{*}{ NM_030783 } \\
\hline PtdSer synthase II antisense & $\begin{array}{l}\text { CCARAARATACTGGCCACARATAC } \\
\text { CTC }\end{array}$ & \\
\hline
\end{tabular}




\section{Table 2:}

The fold change in the expression of fatty acid binding proteins and Acyl-CoA synthetase long-chain family members that occurred upon the induction and was found significant $(\mathrm{p}<0.01)$ in the microarray analysis.

\begin{tabular}{lllc}
\hline Enzyme & Accession & P (+Diff. vs - & Fold Change \\
& number & Diff.) & \\
\hline FABP 5 & NM_001444 & $7.29 \mathrm{E}-06$ & 10.24 \\
\hline Acyl-CoA synthetase long-chain & NM_001995 & $6.11 \mathrm{E}-07$ & \\
family member (ACSL) 1 & & & \\
\hline ACSL 3 & NM_004457 & 0.001 & \\
\hline ACSL 4 & NM_022977 & $6.6 \mathrm{E}-05$ & 11.43 \\
\hline
\end{tabular}




\section{Supplements Table 1: Phospholipase family}

\begin{tabular}{|l|l|l|l|}
\hline Enzyme & $\begin{array}{l}\text { Accession } \\
\text { number }\end{array}$ & $\begin{array}{l}\text { Pv } \\
+ \text { Diff. vs - } \\
\text { Diff. }\end{array}$ & $\begin{array}{l}\text { Fold } \\
\text { Change }\end{array}$ \\
\hline $\begin{array}{l}\text { Phospholipase A2, group IB (pancreas; } \\
\text { PLA2G1B) }\end{array}$ & NM_000928 & 0.117004 & 1.15329 \\
\hline $\begin{array}{l}\text { Phospholipase A2, group IIA (platelets, synovial } \\
\text { fluid; PLA2G2A) }\end{array}$ & NM_000300 & 0.0556868 & 1.20063 \\
\hline Phospholipase A2, group IID (PLA2G2D) & NM_012400 & 0.438031 & 1.07725 \\
\hline Phospholipase A2 group IIE (PLA2G2E) & NM_014589 & 0.0410931 & -1.13234 \\
\hline Phospholipase A2 group IIF (PLA2G2F) & NM_022819 & 0.0754624 & 1.11205 \\
\hline Phospholipase A2 group III (PLA2G3) & NM_015715 & 0.0198896 & 1.16948 \\
\hline $\begin{array}{l}\text { Phospholipase A2, group IVA (cytosolic, } \\
\text { calcium-dependent; PLA2G4A) }\end{array}$ & NM_024420 & 0.00253971 & 4.28091 \\
\hline $\begin{array}{l}\text { Phospholipase A2, group IVB (cytosolic; } \\
\text { PLA2G4B) }\end{array}$ & NM_005090 & 0.0236319 & 1.15076 \\
\hline $\begin{array}{l}\text { Phospholipase A2, group IVC (cytosolic, } \\
\text { calcium-independent PLA2G4C) }\end{array}$ & NM_003706 & 0.00136685 & 1.8867 \\
\hline $\begin{array}{l}\text { Phospholipase A2, group IVD (cytosolic; } \\
\text { PLA2G4D) }\end{array}$ & NM_178034 & 0.519855 & 1.07338 \\
\hline Phospholipase A2, group IVE (PLA2G4E) & NM_001080490 & 0.577801 & 1.03791 \\
\hline Phospholipase A2, group IVF (PLA2G4F) & NM_213600 & 0.0130975 & 1.12463 \\
\hline Phospholipase A2, group V (PLA2G5) & NM_000929 & 0.24853 & -1.63913 \\
\hline $\begin{array}{l}\text { Phospholipase A2, group VI (cytosolic, calcium- } \\
\text { independent (PLA2G6) }\end{array}$ & NM_003560 & 0.322225 & 1.09351 \\
\hline fhostor acetylhydrolase; PLA2G7) & NM_005084 & 0.139557 & 1.3275 \\
\hline Phospholipase A2, group X (PLA2G10) & 0.128626 & 1.17302 \\
\hline
\end{tabular}




\begin{tabular}{|c|c|c|c|}
\hline Phospholipase A2, group XIIA (PLA2G12A) & NM_030821 & 0.0338763 & -1.23194 \\
\hline Phospholipase A2, group XIIB (PLA2G12B) & NM_032562 & 0.0800661 & 1.05786 \\
\hline Phospholipase B1 (PLB1) & NM_153021 & 0.205506 & 1.09005 \\
\hline $\begin{array}{l}\text { Phospholipase C, beta } 1 \text { (phosphoinositide- } \\
\text { specific; PLCB1) }\end{array}$ & NM_182734 & $\begin{array}{l}0.00022945 \\
4\end{array}$ & 3.68169 \\
\hline Phospholipase C, beta 2 (PLCB2) & NM_004573 & 0.227972 & 1.09475 \\
\hline $\begin{array}{l}\text { Phospholipase C, beta } 3 \text { (phosphatidylinositol- } \\
\text { specific; PLCB3) }\end{array}$ & NM_000932 & 0.0169165 & -1.18872 \\
\hline Phospholipase C, beta 4 (PLCB4) & NM_000933 & 0.0288829 & -2.83947 \\
\hline Phospholipase C, gamma 1 (PLCG1) & NM_002660 & 0.00668083 & 1.40432 \\
\hline $\begin{array}{l}\text { Phospholipase C, gamma } 2 \\
\text { (phosphatidylinositol-specific; PLCG2) }\end{array}$ & NM_002661 & 0.0168439 & 1.2383 \\
\hline Phospholipase C, delta 1 (PLCD1) & NM_006225 & 0.413757 & -1.15326 \\
\hline Phospholipase C, delta 3 (PLCD3) & NM_133373 & 0.0333648 & -1.19087 \\
\hline Phospholipase C, delta 4 (PLCD4) & NM_032726 & 0.538663 & 1.16461 \\
\hline Phospholipase C, epsilon 1 (PLCE1) & NM_016341 & 0.00386173 & -5.53743 \\
\hline Phospholipase C, zeta 1 (PLCZ1) & NM_033123 & 0.0425366 & 1.072 \\
\hline Phospholipase C, eta 1 (PLCH1) & NM_014996 & 0.179965 & 1.08134 \\
\hline Phospholipase C, eta 2 (PLCH2) & NM_014638 & 0.158536 & -1.08059 \\
\hline $\begin{array}{l}\text { Phospholipase D1, (phosphatidylcholine-specific; } \\
\text { PLD1) }\end{array}$ & NM_002662 & 0.0023179 & 4.65278 \\
\hline Phospholipase D2 (PLD2) & NM_002663 & 0.0174509 & 1.64138 \\
\hline Phospholipase D family, member 3 (PLD3) & NM_001031696 & 0.0353565 & 1.11496 \\
\hline Phospholipase D family, member 4 (PLD4) & NM_138790 & 0.847484 & 1.01576 \\
\hline Phospholipase D family, member 5 (PLD5) & NM_152666 & 0.452104 & 1.07015 \\
\hline
\end{tabular}


Table 2: Cyclooxygenase pathway

\begin{tabular}{|c|c|c|c|c|}
\hline Enzyme & Process & $\begin{array}{l}\text { Accession } \\
\text { number }\end{array}$ & $\begin{array}{l}\text { Pv } \\
+ \text { Diff. vs - } \\
\text { Diff. }\end{array}$ & $\begin{array}{l}\text { Fold } \\
\text { Change }\end{array}$ \\
\hline $\begin{array}{l}\text { Prostaglandin } \mathrm{G} / \mathrm{H}\left(\mathrm{PGH}_{2}\right) \\
\text { synthase } 1[\mathrm{Cyclooxygenase} 1 \\
(\mathrm{COX}-1)]\end{array}$ & $\begin{array}{l}\mathrm{ARA} \rightarrow \\
\mathrm{PGG}_{2} / \mathrm{PGH}_{2}\end{array}$ & NM_000962 & 0.106273 & 1.33669 \\
\hline $\mathrm{PGH}_{2}$ synthase $2[\mathrm{COX}-2]$ & $\begin{array}{l}\mathrm{ARA} \rightarrow \\
\mathrm{PGG}_{2} / \mathrm{PGH}_{2}\end{array}$ & NM_000963 & 8.23E-07 & 41.7132 \\
\hline Prostacyclin $\left(\mathrm{PGI}_{2}\right)$ synthase 2 & $\mathrm{PGH}_{2} \rightarrow \mathrm{PGI}_{2}$ & NM_000961 & $8.42 \mathrm{E}-06$ & -9.27937 \\
\hline Prostaglandin $\mathrm{E}\left(\mathrm{PGE}_{2}\right)$ synthase & $\begin{array}{l}\mathrm{PGH}_{2} \rightarrow \mathrm{PGE}_{2} \\
(\text { key enzyme) }\end{array}$ & NM_004878 & $1.35 \mathrm{E}-08$ & 15.2885 \\
\hline Prostaglandin $\mathrm{E}\left(\mathrm{PGE}_{2}\right)$ synthase 2 & $\mathrm{PGH}_{2} \rightarrow \mathrm{PGE}_{2}$ & NM_025072 & 0.143423 & 1.10351 \\
\hline Prostaglandin E $\left(\mathrm{PGE}_{2}\right)$ synthase 3 & $\mathrm{PGH}_{2} \rightarrow \mathrm{PGE}_{2}$ & NM_006601 & 0.0234323 & -1.22191 \\
\hline $\begin{array}{l}\text { Prostaglandin } \mathrm{D}\left(\mathrm{PGD}_{2}\right) \text { synthase } \\
(21 \mathrm{kDA} \text { brain })\end{array}$ & $\mathrm{PGH}_{2} \rightarrow \mathrm{PGD}_{2}$ & NM_000954 & 0.0368164 & -1.36101 \\
\hline $\begin{array}{l}\text { Prostaglandin } \mathrm{D}\left(\mathrm{PGD}_{2}\right) \text { synthase } \\
\text { hematopoietic }\end{array}$ & $\mathrm{PGH}_{2} \rightarrow \mathrm{PGD}_{2}$ & NM_014485 & 0.44254 & 1.04544 \\
\hline Prostaglandin $\mathrm{F}\left(\mathrm{PGF}_{2}\right)$ synthase & $\mathrm{PGH}_{2} \rightarrow \mathrm{PGF}_{2 \alpha}$ & NA & NA & NA \\
\hline $\begin{array}{l}\text { Thromboxane } \mathrm{A}_{2}\left(\mathrm{TXA}_{2}\right) \text { synthase } \\
1\end{array}$ & $\mathrm{PGH}_{2} \rightarrow \mathrm{TXA}_{2}$ & NM_001061 & $\begin{array}{l}0.0065247 \\
8\end{array}$ & 1.48198 \\
\hline
\end{tabular}


Table 3: Lipoxygenase pathway

\begin{tabular}{|l|l|l|l|l|}
\hline Enzyme & Process & $\begin{array}{l}\text { Accession } \\
\text { number }\end{array}$ & $\begin{array}{l}\text { Pv } \\
\text { +Diff. vs - } \\
\text { Diff. }\end{array}$ & $\begin{array}{l}\text { Fold } \\
\text { Change }\end{array}$ \\
\hline $\begin{array}{l}\text { Arachidonate 12- } \\
\text { lipoxygenase }\end{array}$ & $\begin{array}{l}\text { PGH2 } \rightarrow \text { 12 hydroperoxy- } \\
\text { eicosatetraenoic acid (12-HPETE) }\end{array}$ & NM_000697 & 0.696827 & 1.0219 \\
\hline $\begin{array}{l}\text { Arachidonate 5- } \\
\text { lipoxygenase }\end{array}$ & PGH2 $\rightarrow$ 5-HPETE & NM_000698 & 0.95781 & 1.00323 \\
\hline $\begin{array}{l}\text { Arachidonate 15- } \\
\text { lipoxygenase }\end{array}$ & PGH2 $\rightarrow$ 15-HPETE & NM_001140 & 0.0648152 & 1.27489 \\
\hline
\end{tabular}

Table 4: Cytochrome P450 pathway.

\begin{tabular}{|l|l|l|l|l|}
\hline Enzyme & Process & $\begin{array}{l}\text { Accession } \\
\text { number }\end{array}$ & $\begin{array}{l}\text { Pv } \\
\text { +Diff. vs - } \\
\text { Diff. }\end{array}$ & $\begin{array}{l}\text { Fold } \\
\text { Change }\end{array}$ \\
\hline $\begin{array}{l}\text { Cytochrome P450 } \\
\text { family 51 (CYP51A1) }\end{array}$ & $\begin{array}{l}\text { PGH2 } \rightarrow \text { epoxy- } \\
\text { eicosatrienoic acids (EETs) }\end{array}$ & NM_000786 & 0.000712437 & -1.84349 \\
\hline
\end{tabular}


Table 5: Fatty acid binding proteins and long chain family member acyl-coA

\begin{tabular}{|l|l|l|l|}
\hline Enzyme & $\begin{array}{l}\text { Accession } \\
\text { number }\end{array}$ & $\begin{array}{l}\text { Pv } \\
\text { +Diff. vs -Diff. }\end{array}$ & Fold Change \\
\hline Fatty acid binding protein (FABP) 1, liver & NM_001443 & 0.32333 & 1.05729 \\
\hline FABP 2, intestinal & NM_000134 & 0.833212 & 1.01753 \\
\hline FABP 7, brain & NM_001446 & 0.14977 & 1.06952 \\
\hline FABP 3, muscle and heart & NM_004102 & 0.0425585 & -3.16309 \\
\hline FABP 4, adipocyte & NM_001442 & 0.104563 & 1.07656 \\
\hline FABP 5 (psoriasis-associated)(EFABP) & NM_001444 & 0.00000800269 & 10.2446 \\
\hline FABP 6, ileal (gastrotropin) & NM_001445 & 0.0218595 & 1.17291 \\
\hline FABP 7, brain & NM_001446 & 0.14977 & 1.06952 \\
\hline $\begin{array}{l}\text { Acyl-CoA synthetase long-chain family } \\
\text { member (ACSL) 1 }\end{array}$ & NM_001995 & 0.000000610651 & 5.77037 \\
\hline ACSL 3 & NM_004457 & 0.00106515 & 2.94836 \\
\hline ACSL 4 & NM_022977 & 0.0000660307 & 11.4308 \\
\hline ACSL 5 & NM_203380 & 0.0369948 & -1.31453 \\
\hline ACSL 6 & NM_001009185 & 0.229006 & 1.01938 \\
\hline
\end{tabular}


bioRxiv preprint doi: https://doi.org/10.1101/2021.01.17.427010; this version posted January 18, 2021. The copyright holder for this preprint (which was not certified by peer review) is the author/funder. All rights reserved. No reuse allowed without permission. 